University of North Florida

UNIVERSITY of

NORTH FLORIDA.

UNF Digital Commons

2-1983

\title{
The Hidden Epidemic: Opiate Addiction and Cocaine Use in the South, 1860-1920
}

David T. Courtwright

University of North Florida, dcourtwr@unf.edu

Follow this and additional works at: https://digitalcommons.unf.edu/ahis_facpub

Part of the History Commons

\section{Recommended Citation}

Courtwright, David T., "The Hidden Epidemic: Opiate Addiction and Cocaine Use in the South, 1860-1920" (1983). History Faculty Publications. 3.

https://digitalcommons.unf.edu/ahis_facpub/3

This Article is brought to you for free and open access by the Department of History at UNF Digital Commons. It has been accepted for inclusion in History Faculty Publications by an authorized administrator of UNF Digital Commons. For more information, please contact Digital Projects.

(C) 2-1983 All Rights Reserved

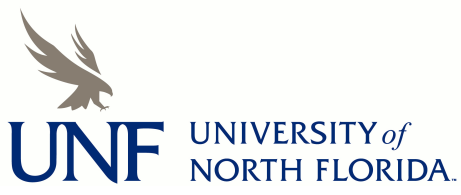




\title{
The Hidden Epidemic: Opiate Addiction and Cocaine Use in the South, 1860-1920
}

\author{
By David T. Courtwright
}

O

NE OF THE MANY MEMORABLE ChaRaCters IN HARPER LeE'S novel, To Kill a Mockingbird, is an aged morphine addict, Mrs. Henry Lafayette Dubose. Mrs. Dubose was a cantankerous widow who lived in Maycomb, a small, fictitious Alabama town. She had been addicted many years before by her physician, who gave her morphine to ease her pain. Informed that she had only a short while to live, she struggled to quit taking the drug, for she was determined "to leave this world beholden to nothing and nobody."

There were tens of thousands of real-life Mrs. Duboses scattered throughout the postbellum South. With the possible exception of the Chinese, southern whites had the highest addiction rate of any regional racial group in the country, and perhaps one of the highest in the world. At the same time southern blacks had a relatively low rate of addiction, at least with respect to opiates. Blacks, when they used drugs at all, tended to use cocaine. It has been alleged-and heatedly denied-that black cocaine use manifested itself in a major crime wave around the turn of the century. Even discounting these reports, it is apparent that the postbellum South had an unusually severe narcotic problem characterized by racial preferences for different drugs.

Documenting this pattern of drug use is difficult since users tended to conceal their practices for fear of social or legal reprisals. There are, nevertheless, a few sources of statistical data. The most important of these is a by-product of the 1914 Harrison Narcotic Act, which was designed to regulate the sale and distribution of narcotics, defined primarily as the opiates and cocaine. The fateful 104.

' Lee, To Kill a Mockingbird (Philadelphia and New York, 1960), 94-105; quotation on p.

Mr. Courtwright is chairman of the Department of History at the University of Hartford. 


\section{TABLE 1}

Number of Opiate Addicts per Thousand Residents Attending Clinics in Eleven Southern Cities

Atlanta, Georgia

Augusta, Georgia

Macon, Georgia

Paducah, Kentucky

New Orleans, Louisiana

Shreveport, Louisiana

9.550

Shreveport, Louisiana (revised estimate)

4.809

Durham, North Carolina

1.658

Knoxville, Tennessee

2.364

Memphis, Tennessee

2.002

Houston, Texas

Clarksburg, West Virginia

Average number of addicts per thousand

for eleven cities using revised Shreveport

estimate

Sources: Lawrence Kolb and A. G. Du Mez, "The Prevalence and Trend of Drug Addiction in the United States and Factors Influencing It," Public Health Reports, XXXIX (May 23, 1924), 1182; Charles E. Terry and Mildred Pellens, The Opium Problem (Montclair, N. J., 1970), 40-41, for the revised Shreveport figure.

weakness of the Harrison Act was its failure to resolve the issue of maintenance; that is, could a physician legally supply an addict with drugs for the sole purpose of supporting his or her habit? After years of pressure from the Treasury Department the Supreme Court finally decided in March 1919 that physicians might not maintain addicted patients. Consequently many addicts, denied a legal source of opiates, were forced to turn to the black market. However, many municipalities, for both practical and humanitarian reasons, responded to this crisis by establishing narcotic clinics, which were designed to supply narcotics to, and in some instances to treat, addicted persons. But the federal government continued to pursue its antimaintenance policies, and within two years it had succeeded in closing nearly all the clinics. ${ }^{2}$ Fortunately, however, their records survived, and in 1924 two United States Public Health Service officials, Lawrence Kolb and Andrew G. Du Mez, tabulated the number of addicts attending clinics in thirty-four cities in twelve states. The data for eleven southern cities are set forth in Table 1; those for twenty-three northern and western cities in Table 2.

"In compiling the . . . figures from the reports," Kolb and Du Mez remarked, "the highest number of addicts recorded at any one time or in a certain year are given. . . . No reduction whatever was

${ }^{2}$ For further details on the evolution of the antimaintenance policy see David F. Musto, The American Disease: Origins of Narcotic Control (New Haven, 1973), 54-182. 


\section{TABLE 2}

Number of Opiate Addicts Per Thousand Residents Attending Clinics in Twenty-three Northern and Western Cities

Los Angeles, California .834

San Diego, California

Bridgeport, Connecticut

Hartford, Connecticut

Meriden, Connecticut

New Haven, Connecticut

Norwalk, Connecticut

Waterbury, Connecticut

Albany, New York

Binghamton, New York

Buffalo, New York

Corning, New York

Elmira, New York

Hornell, New York

Middletown, New York

Oneonta, New York

Port Jervis, New York

Rochester, New York

Saratoga Springs, New York $\quad .910$

Syracuse, New York $\quad .536$

Utica, New York $\quad .266$

Youngstown, Ohio $\quad .491$

Providence, Rhode Island $\quad \mathbf{. 7 3 7}$

Average number of addicts per thousand

for twenty-three cities

Source: Lawrence Kolb and A. G. Du Mez, "The Prevalence and Trend of Drug Addiction in the United States and Factors Influencing It," Public Health Reports, XXXIX (May 23, 1924), 1182.

made in the totals for transients, although the reports show that many of the clinics treated addicts from distant as well as near-by places." The average rate for all thirty-four cities was .99 , or almost precisely one addict per thousand residents. Of the cities listed, one in particular stands out: Shreveport's rate of 9.55 addicts per thousand persons was nearly 9.7 times as great as the overall average. Kolb and Du Mez attributed this to the relative longevity of Dr. Willis P. Butler's Shreveport clinic, which was not closed until 1923. As clinics in Houston, New Orleans, and other southern cities were closed addicts made their way to Shreveport, where treatment was available and morphine could still be obtained for six cents a grain. Butler, who was also aware of the problem of transients, later went back through his records, dividing resident patients from nonresident patients. He found that, of 542 cases treated during 1920, 211 
had resided in Caddo Parish a year prior to registration at the clinic, yielding a revised resident rate of approximately 4.8 addicts per thousand. ${ }^{3}$

There are other problems with the clinic data as well. There was, for one, a likelihood of underenumeration because many well-to-do addicts undoubtedly preferred anonymity to cheap drugs. On the other hand, as Kolb and Du Mez pointed out, these totals were also inflated by nonresidents who took advantage of the various maintenance programs. It is difficult to say whether these factors balanced out. But even if the clinic data cannot be used to determine the absolute number of addicts, they do indicate something about their regional distribution. The twenty-three northern and western cities averaged .93 addicts per thousand persons, while the eleven southern cities averaged 1.53 per thousand-a 64.5 percent higher rate. Even controlling for differences in city size, there is only a very slight possibility that the observed difference is due to chance. ${ }^{4}$

Two other, prototypical southern maintenance programs are also of interest. In August 1912 Jacksonville, Florida, passed an ordinance drafted by the city health officer, Charles Edward Terry, requiring that the Health Department be sent duplicate copies of prescriptions for medicines containing more than three grains of morphine or two grains of cocaine or their equivalents. The law also stipulated that the health officer might, upon acquiring "satisfactory evidence of habitual use," offer free prescriptions for narcotics to the addict, to be filled by a local druggist. The system was thus designed to supply narcotics to, as well as to keep track of, addicts. Table 3 represents a classification by drug, race, and sex of those persons registered during the first five months of operation.

Eliminating those who used cocaine alone, there were 383 opiate addicts altogether, a rate of approximately 5.5 per thousand per-

\footnotetext{
${ }^{3}$ Kolb and Du Mez, "The Prevalence and Trend of Drug Addiction in the United States and Factors Influencing It," Public Health Reports, XXXIX (May 23, 1924), 1180-88 (quotation on p. 1182); Case 73790 (Houston), Treasury Department Files, hereinafter cited as TDF (accessed through the Freedom of Information Division of the Drug Enforcement Administration, Washington, D. C.); Charles E. Terry and Mildred Pellens, The Opium Problem (Montclair, N. J., 1970), 40-41. Butler's description of the clinic, "How One American City Is Meeting the Public Health Problems of Narcotic Addiction," appears in American Medicine, XXVIII (March 1922), 154-62.

4 Using the data in Tables 1 and 2 (including the revised Shreveport estimate), a regression of the addiction rate $(A)$ on city population $(P)$ and a dummy variable $(D$, where South $=1$, North and West $=0$ ) yields

$$
\begin{array}{cc}
\hat{A}=1.1435 & -.16357 \times 10^{-s} P \\
(n=34) & (t=-1.47)
\end{array} \quad \begin{gathered}
.84083 D \\
(t=2.60)
\end{gathered}
$$

The relationship between the addiction rate and city size is relatively weak, but the relationship between the addiction rate and the dummy variable, representing regional differences, is significant at $p<.01$.
} 


\section{TABLE 3}

1912 Jacksonvinle Registration/Maintenance Data

\begin{tabular}{lcrrrrr} 
& Percent & White & \multicolumn{2}{c}{ White } & \multicolumn{3}{c}{ Colored } & Colored & Total \\
& of Users & Males & Females & Males & Females & \\
Morphine & 38.85 & 54 & 114 & 15 & 26 & 209 \\
Cocaine & 28.81 & 30 & 23 & 50 & 52 & 155 \\
Laudanum & 18.59 & 14 & 44 & 11 & 31 & 100 \\
Heroin & 4.09 & 10 & 10 & 0 & 2 & 22 \\
Gum Opium & 2.23 & 5 & 3 & 3 & 1 & 12 \\
Cocaine and & & & & & & \\
$\quad$ Opiate Combined & 7.43 & 21 & 10 & 3 & 6 & 40 \\
Totals & 100.00 & 134 & 204 & 82 & 118 & 538
\end{tabular}

Source: City of Jacksonville, Florida, Annual Report of the Board of Health for the Year 1912, pp. 26-27.

\section{TABLE 4}

1913 Jacksonvile Registration/Maintenance Data

\begin{tabular}{|c|c|c|c|c|c|c|}
\hline & $\begin{array}{l}\text { Percent } \\
\text { of Users }\end{array}$ & $\begin{array}{l}\text { White } \\
\text { Males }\end{array}$ & $\begin{array}{c}\text { White } \\
\text { Females }\end{array}$ & $\begin{array}{l}\text { Colored } \\
\text { Males }\end{array}$ & $\begin{array}{l}\text { Colored } \\
\text { Females }\end{array}$ & Total \\
\hline Morphine & 32.92 & 94 & 142 & 20 & 36 & 292 \\
\hline Cocaine & 39.00 & 102 & 109 & 58 & 77 & 346 \\
\hline Laudanum & 12.18 & 23 & 30 & 11 & 44 & 108 \\
\hline Heroin & 3.16 & 19 & 9 & 0 & $\mathbf{0}$ & 28 \\
\hline Gum Opium & 1.58 & 4 & 4 & 3 & 3 & 14 \\
\hline \multirow{2}{*}{$\begin{array}{l}\text { Cocaine and } \\
\text { Opiate Combined }\end{array}$} & & & & & & \\
\hline & 11.16 & 48 & 34 & 6 & 11 & 99 \\
\hline TOTALS & 100.00 & 290 & 328 & 98 & 171 & 887 \\
\hline
\end{tabular}

sons. The following year Terry reported an even higher figure of 541 opiate addicts registered at his clinic (Table 4), although there is evidence that many of the new cases were transients. ${ }^{5}$ But even if the lower 1912 figure is used it appears that the Jacksonville rate was at least five times that of the northern and western clinic average.

Finally, in 1913, the year after the Jacksonville program was formulated, Tennessee passed a law forbidding the refilling of narcotic prescriptions unless the person holding the prescription

s Charles E. Terry, "Habit-Forming Drugs," in City of Jacksonville, Florida, Annual Report of the Board of Health for the Year 1912 (n.p., n.d.), 24-29; ibid., 1913 (n.p., n.d.), 55-58; Terry, "Drug Addictions, a Public Health Problem," American Journal of Public Health, IV (January 1914), 28-37; and Terry and Pellens, Opium Problem, 24-27 (quotation on p. 24). On the influx of transients see Kolb and Du Mez, "Prevalence and Trend," 1201; and Lawrence Kolb to Lawrence C. Kolb, December 12, 1932, Box 6, Lawrence Kolb Papers (History of Medicine Division, U. S. National Library of Medicine, Bethesda, Md.). 
had previously registered with the state as an addict. After a year of operation State Food and Drugs Commissioner Lucius P. Brown reported a total of 2,370 registrants, representing a rate of approximately 1.04 addicts per thousand persons. Brown seriously doubted, however, that all or even a majority of addicts had registered; his best guess was that there were "in the neighborhood of 5,000 addicts in Tennessee." ' It would appear, then, that Tennessee also had an addiction rate in excess of the northern and western clinic average.

Further evidence for higher southern use is found in pharmacy records. A survey of the records of thirty-four Boston drugstores published in 1888 revealed that, of 10,200 prescriptions sampled, 1,481 or 14.5 percent contained some type of opiate.' Unfortunately, there was no comparable study of prescriptions for a major southern city. However, a sampling of the contents of two surviving record books of New Orleans pharmacists dating from the $1870 \mathrm{~s}$ and 1880 s shows that fully 24.5 percent of these prescriptions contained opium or morphine-ten percentage points more than the Boston average. ${ }^{B}$ While a limited, two-city comparison does not prove that an entire region had a higher rate of addiction, it at least corroborates the differences in clinic registration. Taken together, the statistical evidence indicates that the South suffered an inordinately high rate of opiate addiction in comparison to other regions of the continental United States.

The burden of addiction was not borne equally, however. Whites were overrepresented among opium and morphine addicts, blacks underrepresented. In 1885 Dr. James D. Roberts of the Eastern North Carolina Insane Asylum, after making a number of inquiries, reported that he knew "of but three well authenticated cases of opium-eating in the negro." In Jacksonville, nearly three-quarters of the opium and morphine addicts were white, even though whites

"Brown, "Enforcement of the Tennessee Anti-Narcotics Law," American Journal of Public Health, V (April 1915), 323-33; quotation on p. 331.

7 Virgil G. Eaton, "How the Opium-Habit Is Acquired," Popular Science Monthly, XXXIII (September 1888), 665.

- Thirty of a hundred randomly selected entries in the prescription record book of George D. Feldner (Rudolph Matas Medical Library, cited hereinafter as RMML, Tulane University School of Medicine, New Orleans, La.) contained opiates; likewise nineteen of a hundred randomly selected entries in the prescription record book of Erich Brand (Historical Pharmacy Museum of New Orleans). The Feldner sample falls in the years 1886-1889; the Brand sample, 1877-1878. Both druggists were situated on Magazine. Street. Levi Nutt, head of the Narcotic Division of the Prohibition Unit of the Bureau of Internal Revenue, also commented on the high southern rate in U.S. House of Representatives, Exportation of Opium: Hearings Before a Subcommittee of the Committee on Ways and Means on H.R. 14500, 66 Cong., 3 Sess. (Washington, 1921), 133.

'Roberts, "Opium Habit in the Negro," North Carolina Medical Journal, XVI (September 1885), 206-207; quotation on p. 207. 
made up slightly less than half of that city's population. Commissioner Brown noted that not over 10 percent of Tennessee's registrants were black, even though blacks made up roughly one-quarter of that state's population. ${ }^{10}$ In Shreveport, 91.5 and in Houston, 95.5 of the clinic patients were white, remarkable statistics in view of the substantial black population in those areas. ${ }^{11}$ The high overall southern rate of addiction, together with the relatively low number of black addicts, suggests that postbellum southern whites, as a group, suffered an exceedingly high rate of opiate addiction.

The key to understanding both the extent and racial distribution of southern addiction is nineteenth-century medical practice. Most American physicians were ill equipped to cure most diseasesdiseases whose etiology they but dimly understood. The majority of their remedies were useless; some, like calomel, were positively dangerous. Yet at the same time doctors, who received a fee for their professional services, felt compelled to do something for the patient, even if it was only blind, symptomatic treatment. Opiates were thus extremely popular as a way of offering temporary relief for a wide variety of ailments; they were in fact used as a virtual panacea. In 1850 , for example, a young New Orleans physician named John Bernard Vandergriff began compiling a list of prescriptions used to combat various diseases. His notes show that opiates were administered, often in conjunction with other drugs, to treat such diverse conditions as asthma, bronchitis, cholera, chlorosis, colic, diarrhea, dysentery, hemorrhoids, intermittent fever, and leukorrhea. They were also recommended as a general anodyne and "anti-emetic," and even as a treatment for distemper in horses. ${ }^{12}$

If the opiates were popular at mid-century, they were even more so after the 1860 s and 1870 s, when the spread of hypodermic medication gave doctors a powerful new technique for administering morphine, whose soothing, analgesic effects were almost immediately felt. As New Orleans surgeon Charles Schuppert put it, an

1" Brown, "Enforcement of Tennessee Law," 330-31; see Tables 3 and 4 for Jacksonville.

"Dan Waldorf, Martin Orlick, and Craig Reinarman, Morphine Maintenance: The Shreveport Clinic, 1919-1923 (Washington, D. C., 1974), 28; memorandum to L. G. Nutt, March 26, 1920, Houston file, Case 73790, TDF. Southern clinics, like much else in southern life, were segregated. New Orleans, for example, had separate entrances for white males, white females, and "colored" patients. M. W. Swords, "A Résumé of Facts and Deductions Obtained by the Operation of a Narcotic Dispensary," American Medicine, XXVI (January 1920), 25-26. In spite of the segregated facilities, I have uncovered no evidence to suggest that blacks were denied access to the clinics. Since a major goal of these programs was to preempt the illicit traffic in narcotics, they necessarily catered to all groups. Had black addicts been excluded, they would have been forced to resort to crime to pay the peddlers' high prices-and this was something that both local police and public health officials earnestly wished to avoid.

12 Vandergriff, "Pharmaceutical Preparations and Select Prescriptions" (MS, 1850; RMML), 77, 79, et passim. 
injection of morphine "acted like a charm," alleviating the symptoms and lifting the spirits of the ill and injured. ${ }^{13}$ The danger, however, was that patients, especially if they suffered from some chronic, painful condition, might become physically dependent through repeated administrations of the drug. Physical dependence is the state in which discontinuation of an opiate will bring on a train of characteristic withdrawal symptoms: yawning, sneezing, sweating, severe cramps, diarrhea, vomiting, and others. Once the dependent patient learned to banish these withdrawal symptoms by merely taking another dose, then he or she became a full-blown addict, using opiates on a daily basis. ${ }^{14}$

Treatment by physicians, it should be added, was not the only cause of opiate addiction. Some addicts undoubtedly owed their plight to self-medication, either with patent medicines or home remedies containing opiates. The recipe book of Texas pioneer Anna G. McKenney, for example, lists several medications for cholera, diarrhea, and chills in which laudanum (tincture of opium) was an active ingredient. ${ }^{15}$ It is unlikely, however, that the occasional swig of a narcotic nostrum or dose of a folk remedy created as many addicts as did the direct administration of opium or one of its alkaloids by physicians. Remarks in the medical literature, ${ }^{16}$ as well as a number of statistical studies, ${ }^{17}$ indicate that a majority of

${ }^{13}$ Schuppert, "Notes, Case Records and Observations, Charity Hospital Medical College" (MS, 1875-1879; RMML), 54.

14 For more on the addiction process see Alfred R. Lindesmith, Addiction and Opiates (Chicago, 1968), 23-155. It should be noted that the term "addiction"' is used here for convenience and consistency; nineteenth-century addicts were called "opium eaters," "morphine eaters," "morphinists," and various other names.

is "Mrs. McKenney's Cook Book," MS, n.d., 1830?-1860? (Texas History Research Library, The Alamo, San Antonio, Texas), 77, 83, 88, 91.

${ }^{16}$ Of the dozens of journal articles that attributed the bulk of opium and morphine addiction to physicians, the following are typical: J.S. Weatherly, "Increase in the Habit of Opium Eating," Medical Association of the State of Alabama, Transactions, no vol. (1869), 67; H. S. Duncan, "The Morphia Habit-How Is It Most Usually Contracted, and What Is the Best Means to Diminish It?"' Nashville Journal of Medicine and Surgery, N.S., XXXV (June 1885), 247; Harry M. Nickerson, "The Relation of the Physician to the Drug Habit," Journal of Medicine and Science, VI (January 1900), 50; and Brown, "Enforcement of Tennessee Law," 329.

${ }^{17}$ Terry, "Drug Addictions," 32, concluded that physicians were responsible for about 55 percent of the cases of opiate addiction that he observed, the remainder being divided among self-medication on the advice of friends (21.6 percent), "dissipation" (21.2 percent), and "chronic incurable disease" ( 2.4 percent). These figures were based on a subsample of 213 users. See also Lyman F. Kebler, "The Present Status of Drug Addiction in the United States," Monthly Cyclopaedia and Medical Bulletin, IV (January 1911), 15; and the manuscript case records on oversized sheets, Box 6, Kolb Papers. The latter were described by Kolb as "representing . . . addicts in various situations, from various walks of life, and in widely separated sections of the country, [and] may be considered fairly representative of the addict population as a whole." Kolb, "Types and Characteristics of Drug Addicts," Mental Hygiene, IX (April 1925), 300. There are 230 decipherable cases altogether, including 174 opium and morphine, 40 heroin, 7 smoking opium, 7 cocaine only, and 2 veronal. Most of 
nineteenth-century and early-twentieth-century addicts could trace their condition back to narcotics provided by their doctors.

The simplest way to avoid addiction, then, was to stay healthy, stay away from patent medicines, and, above all, stay away from hypodermic-wielding physicians. Unfortunately, this was something that relatively few southerners could do. The postbellum South was an insalubrious place; diarrhea, dysentery, and malaria were all widespread, endemic diseases. ${ }^{18}$ Opiates, which possess constipating as well as analgesic properties, were very commonly used to treat diarrheal disorders. ${ }^{19}$ They were also commonly used to relieve the paroxysms of malaria. ${ }^{20}$ Since diarrhea, dysentery, and malaria were often chronic, debilitating diseases, the administration of opiates every time the symptoms recurred could easily lead to physical dependence, thence to addiction. There was, by way of comparison, a similar problem in the English Fenland, the lowlying country in and around Cambridgeshire. The Fens were one of the most unhealthy areas in nineteenth-century England, the residents allegedly 'prone to the ague, 'painful rheumatisms,' and neuralgia." The presence of these endemic diseases was, according to Virginia Berridge, a leading scholar of Victorian drug use, one important reason why the region had an exceedingly high rate of opium consumption. ${ }^{21}$

the case histories were taken in late 1923 or shortly thereafter. Of the 171 opium and morphine addicts whose backgrounds were known, 41.5 percent were designated as "physician," 25.1 percent as "self-medication," and 22.2 percent as "associates." Another category, 11.1 percent, consisted of those who were introduced to the drug by a physician but continued use on their own. Thus, physicians were directly or indirectly responsible for over half (52.6 percent) of all the opium and morphine cases in Kolb's sample.

10 William H. Deaderick and Loyd Thompson, The Endemic Diseases of the Southern States (Philadelphia and London, 1916), 21, 399; Joseph I. Waring, $A$ History of Medicine in South Carolina, 1825-1900 (Charleston, 1967), 177-79. The prevalence of diarrheal diseases in the South is also reflected in Samuel M. Bemiss, comp., "Record of Cases Attended at Charity Hospital, New Orleans, October 1868-February 1875" (MS; RMML). Note that "diarrhea" and "dysentery" signified in the nineteenth century practically any disease in which the chief symptom was a loose stool (diarrhea) or loose stool with blood and pus (dysentery). Other diseases in which diarrhea was a symptom, such as cholera, or in which diarrhea was sometimes present, such as typhoid fever, were also treated with opium and morphine.

"Anon., "Notes on Dudley's Lectures Taken in 1830" (MS; RMML), 153; the second and sixth cases in Jacob E. Fitch, "Case Records, Charity Hospital, New Orleans" (MS, 1881; RMML); and W. B. Cheadle, "A Lecture on the Clinical Uses of Opium," Clinical Journal, IV (September 26, 1894), 350. Leslie C. Campbell, Two Hundred Years of Pharmacy in Mississippi (Jackson, Miss., 1974), 78, notes that in 1907 paregoric "was being 'abused in Mississippi most grievously." "This is significant, since paregoric is the form of opium commonly given for diarrhea.

${ }^{20}$ John B. Beck, Lectures on Materia Medica and Therapeutics . . . 3d ed., ed. by C. R. Gilman (New York, 1861), 368; and "Opium in Fevers," Journal of the American Medical Association, VIII (March 5, 1887), 265. Kolb and Du Mez, "Prevalence and Trend," 1184, also mention hookworm as a factor, but I have found little evidence that this condition was routinely treated with opiates.

${ }^{21}$ Berridge, "Fenland Opium Eating in the Nineteenth Century," British Journal of 
The Civil War also contributed to southern addiction. Per capita, the South suffered more casualties than the North; there were therefore relatively more wounded or shell-shocked soldiers who were candidates for addiction during or after the conflict. ${ }^{22}$ The Civil War also had an enormous psychological impact on the South; with the realization that a way of life was irretrievably lost came a lingering, pervasive depression, especially among the planter elite. One knowledgeable New York opium dealer thought he saw a connection between the South's increased opiate consumption and its postwar malaise. "Since the close of the war," he remarked in 1877 , "men once wealthy, but impoverished by the rebellion, have taken to eating and drinking opium to drown their sorrows." 23 Women, too, he might have added; they had their own war-related troubles, and the opiates were especially attractive as a semirespectable substitute for alcohol. ${ }^{24}$

The Civil War also provides a clue as to why blacks had a relatively low rate of addiction; Confederate defeat was for most of them an occasion of rejoicing rather than profound depression. This was almost certainly not as important, however, as the fact that blacks generally lacked access to professional medical care. Because they were poor, because they were discriminated against, and because there were relatively few doctors of their own race, blacks could not avail themselves of physicians' services as often as did southern whites. ${ }^{25}$ While this may have exacerbated their high rates

Addiction to Alcohol and Other Drugs, LXXII (September 1977), 275-84; quotation on p. 275.

${ }^{22}$ On the role of the war in fostering addiction see David T. Courtwright, "Opiate Addiction as a Consequence of the Civil War," Civil War History, XXIV (June 1978), 101-11.

23 "Opium and Its Consumers," New York Tribune, July 10, 1877, p. 2. Gaines M. Foster, who has investigated the impact of the war on alcohol consumption, writes that drink may also have served as an escape for some embittered southerners, though the extent of this phenomenon is by no means clear. Personal correspondence.

${ }^{24}$ T. J. Happel, "The Opium Curse and Its Prevention," Medical and Surgical Reporter, LXXII (May 25, 1895), 727-31; John S. Haller, Jr., and Robin M. Haller, The Physician and Sexuality in Victorian America (Urbana, Chicago, and London, 1974), 302. Other reasons for the relatively large numbers of women addicts, both North and South, were the use of opiates to treat "female troubles," especially dysmenorrhea, and the propensity of male physicians to diagnose the ailments of their female patients as "nervous disorders" and then to treat them with the tranquilizing opiates. See also Fred H. Hubbard, The Opium Habit and Alcoholism (New York, 1881), 17. W. P. Crumbacker to Hamilton Wright, September 3, 1908, Records of the United States International Opium Commission and Conference, Record Group 43 (National Archives, Washington, D. C.; hereinafter cited as USIOC Records); and Brown, "Enforcement of Tennessee Law," 332-33.

${ }^{25}$ Horace W. Conrad, "The Health of the Negroes in the South: The Great Mortality Among Them; the Causes and Remedies," Sanitarian, XVIII (June 1887), 505, 507; W. E. Burghardt Du Bois, ed., The Health and Physique of the Negro American (Atlanta, 1906), 110; Herbert M. Morais, The History of the Negro in Medicine (New York, 1967), 85-86; and Marshall S. Legan, "Disease and the Freedmen in Mississippi During Reconstruction," Journal of the History of Medicine and Allied Sciences, XXVIII (July 1973), 267. 
of morbidity and mortality, it at least conferred an ironic benefit: freedom from iatrogenic, or physician-caused, opiate addiction.

Two other factors also help to explain the lower black rate of addiction, although these should be considered of secondary importance. First, blacks tended to be younger than whites. In 1890, for example, the median age of blacks was 18.1 years; whites, 22.5 years. ${ }^{26}$ Stated another way, relatively more whites survived to middle age and beyond. This is significant because many of the chronic diseases commonly treated with opiates (such as arthritis, rheumatism, or delirium tremens) were conditions observed primarily among older patients, Mrs. Dubose again serving as a prime example. Second, it is now known that southern blacks, for a variety of complex genetic reasons, suffered fewer and less severe cases of malaria. ${ }^{27}$ Since malaria was one of the chronic diseases treated symptomatically with opiates, this also conferred a slight advantage on blacks, from the standpoint of avoiding addiction.

The low rate of opiate addiction among southern blacks, however, does not necessarily mean that they were entirely drug free. Although opiates were by all odds the leading drug of addiction during the nineteenth and early twentieth centuries, other drugs, notably cocaine, were also overused. In the mid-1880s many American physicians, encouraged by the glowing reports of Sigmund Freud and other cocaine enthusiasts, administered the drug for a wide variety of ailments; cocaine, like opium and morphine, became something of a panacea. ${ }^{28}$ Within a few years, however, more conservative physicians launched a counterattack, warning their colleagues in articles and speeches of the danger of creating "cocainists." 29

Just as these animadversions began to have an effect growing numbers of blacks were beginning to use cocaine for other, essentially nonmedical, reasons. It appears that blacks were introduced to cocaine sometime in the late 1880 s or 1890 s when New Orleans stevedores began taking the drug to help them endure long spells of loading and unloading steamboats, a task at which they labored for up to seventy hours at a stretch. ${ }^{30}$ In this respect they resembled

${ }^{26}$ U. S. Bureau of the Census, Historical Statistics of the United States: Colonial Times to 1970 (2 pts., Washington, 1975), Part 1, Series A-146 and A-149, p. 19. The hypothesis that age differences might be associated with the unbalanced racial distribution of addicts was suggested to me by Gerald N. Grob.

${ }^{27}$ Todd L. Savitt, Medicine and Slavery: The Diseases and Health Care of Blacks in Antebellum Virginia (Urbana, Chicago, and London, 1978), 17-35.

21 Sigmund Freud, Cocaine Papers, edited by Robert Byck with notes by Anna Freud (New York, 1974), especially xvii-xxxix, 49-88, 121-50.

29 For example, J. B. Mattison, “Cocainism," Medical Record, XLII (October 22, 1892), 474-77; XLIII (January 14, 1893), 34-36.

30 "Negro Cocaine Fiends," Medical News, LXXXI (November 8, 1902), 895; also abstracted as "The Cocaine Habit Among Negroes," British Medical Journal (November 
South American natives, who chewed coca leaves to increase their nervous energy, avoid drowsiness, and "bear cold, wet, great bodily exertion, and even want of food . . . with apparent ease and impunity." ${ }_{31}$ Whether these stevedores took to cocaine on their own initiative, or whether they were introduced to the drug by their foremen, is not known. It is known, however, that the use of cocaine by black laborers soon spread from New Orleans to other parts of the South, to cotton plantations, railroad work camps, and levee construction sites. " "Well, the cocaine habit is might' bad," ran one work song, "It kill ev-ybody I know it to have had." ${ }^{33}$ Other blacks sniffed cocaine, not as a stimulus to work, but as a form of dissipation..$^{34}$ Altogether, there were proportionately more black cocaine users than white. In Jacksonville, for example, area blacks had a rate of cocaine use almost twice that of white residents in $1912 .{ }^{35}$ Southern police chiefs who responded to a national survey on drug use in 1908 and 1909 stated that there were relatively more black cocaine users than white, an opinion shared by their northern colleagues. ${ }^{36}$ Prison statistics, although fragmentary, are consistent with the belief that cocaine was more popular among blacks than whites. ${ }^{37}$

29, 1902), Part 2, p. 1729. See also George E. Pettey, The Narcotic Drug Diseases and Allied Ailments: Pathology, Pathogenesis, and Treatment (Philadelphia, 1913), 426.

" J. T. Whittaker, "Cocaine in the Treatment of the Opium Habit," Medical News, XLVII (August 8, 1885), 148. See also G. Archie Stockwell, "Erythroxylon Coca," Boston Medical and Surgical Journal, XCVI (April 5, 1877), 401.

32 "The Cocaine Habit Among Negroes," 1729; Harris Dickson to Hamilton Wright, December 7, 1909, USIOC Records.

${ }^{33}$ Cited in Lawrence W. Levine, Black Culture and Black Consciousness: Afro-American Folk Thought from Slavery to Freedom (New York, 1977), 283. On the basis of his study of black music Levine believes that cocaine use was common among southern blacks, although he doubts that the drug provoked interracial violence as some have alleged. Personal correspondence. I am indebted to Eugene D. Genovese for calling my attention to Levine's work.

${ }^{34}$ "Cocaine Alley," American Druggist and Pharmaceutical Record, XXXVII (December 10, 1900), 337-38; "The Cocain Habit," Journal of the American Medical Association, XXXVI (June 23, 1900), 330.

${ }^{33}$ From Table 3, not counting combination opiate-cocaine users or the occasional cocaine users who failed to find their way into Terry's program. The following year the situation was reversed, but only, as has been already noted, after a large influx of outside users. It is my view that the original 1912 data best represent the Jacksonville situation.

${ }^{36}$ Representative of the southern authorities were Colonel Swan in "Baltimore Notes" (MS, 1908), no pp.; and W. P. Ford of Norfolk, Va., to Hamilton Wright, June 18, 1909, USIOC Records. For the views of northern and midwestern police chiefs who wrote to Wright see for example J. J. Donahue of Omaha, June 21, 1909; A. G. Miller of Des Moines, June 21, 1909; and Thomas A. McQuaide of Pittsburgh, June 29, 1909, ibid.

${ }^{37}$ Two prison physicians, $O$. J. Bennet of the Western Penitentiary of Pennsylvania and Frank A. McGuire of the City Prison of New York, stated that blacks tended to use cocaine more than whites. Bennet found that 7 of 682 inmates examined over a two-year period admitted the use of cocaine and that all were black. "My candid opinion of the matter," he was quoted as saying, "is that the use of . . . [cocaine] is increasing rapidly, especially among the black population." Thomas G. Simonton, "The Increase of the Use of Cocaine Among the Laity in Pittsburgh," Philadelphia Medical Journal, XI (March 28, 1903), 558; McGuire 
Less clear are the behavioral implications of cocaine use by blacks. From 1900 to 1914 several white authorities claimed that blacks, crazed by cocaine, went on superhuman rampages of violence. ". . . many of the horrible crimes committed in the Southern States by the colored people can be traced directly to the cocaine habit," charged Colonel J. W. Watson of Georgia in $1903 .{ }^{38}$ Others who sounded variations on this theme included New Orleans district attorney St. Clair Adams, Vicksburg municipal court judge Harris Dickson, New Jersey physician Edward Huntington Williams, and Dr. Hamilton Wright, a leading member of the United States Opium Commission. ${ }^{39}$ Police officials were also concerned with cocaine's exciting effects. "When negroes get too much of it," wrote Louisville police chief Jacob H. Haager, "they are inclined to go on the war-path, and when in this condition they give a police officer who attempts to arrest them . . . a hard time."40

to Wright, August 4, 1908, USIOC Records. Years later blacks were still overrepresented among federal drug prisoners who used only cocaine; of eleven such cases listed in U. S. House of Representatives, Establishment of Two Federal Narcotic Farms: Hearings Before the Committee on the Judiciary, 70 Cong., 1 Sess. (Washington, 1928), 140-47, 151-60, four were black, six were white, and one was Mexican. There is one contrary article, E. M. Green, "Psychoses Among Negroes-A Comparative Study," Journal of Nervous and Mental Disease, XLI (November 1914), 702, to the effect that cocaine was a factor in only 2 of 2,119 black cases admitted to the Georgia State Sanitarium between January 1, 1909, and January 1, 1914. Green thought cocaine sufficiently expensive and disruptive of working ability that few blacks could afford its habitual use, hence few psychoses resulted. However, that was in the years 1909 to 1914, well after adverse legislation had driven up the price of the drug. Green's statistics, moreover, do not of themselves prove a low incidence of cocaine use among Georgia blacks; they prove only that cocaine-using blacks were not confined in Georgia sanitaria. Either cocaine psychosis was uncommon or, when it occurred, some other agency dealt with it. The latter would apply especially to incidents involving theft or violence, which would more likely terminate in prison, or at the end of a rope, than in an asylum. Note too that Green's analysis does not apply to occasional black cocaine use, which would not have been likely to produce psychoses.

38 "Cocaine Sniffers," New York Tribune, June 21, 1903, Pt. II, p. 11.

39 "Aaron Martin Sold 470 Ounces of Cocaine in Nine Months," New Orleans Item, n.d., n.p., clipping in USIOC Records; Charles W. Collins and John Day, "Dope, the New Vice: Part 1, the Eighth Deadly Sin," Everyday Life, IV (July 1909), 4, 29; Edward H. Williams, "Negro Cocaine 'Fiends' Are a New Southern Menace," New York Times, February 8, 1914, Sec. 5, p. 12; and Williams, "The Drug-Habit Menace in the South," Medical Record, LXXXV (February 7, 1914), 247-49; Hamilton Wright, Report on the International Opium Commission and on the Opium Problem as Seen Within the United States and Its Possessions (Senate Documents, 61 Cong., 2 Sess., No. 377, Serial 5657, Washington, 1910), 48-50; and U. S. House of Representatives, Importation and Use of Opium: Hearings Before the Committee on Ways and Means on H. 25240-42 and 28971 . , , 61 Cong., 3 Sess. (Washington, 1911), 83.

'Haager to Wright, July 9, 1909, USIOC Records. Other police chiefs who corresponded with Wright also stated that cocaine was an incentive to crime, without going into particulars. See J. J. Reagan of Lexington, Ky., June 17, 1909; W. P. Ford of Norfolk, Va., June 18, 1909; and E. E. Creecy of St. Louis, June 21, 1909, ibid. It should be added that all these police of ficials were replying to a routine letter of inquiry and had no apparent motive for distortion. See also [Louis] Werner, "The Illegal Sale of Cocaine," in International Association of Chiefs of Police, The Police Yearbook ... Containing the Proceedings of the Sixteenth Annual Session (Grand Rapids, Mich., 1909), 84-86. 
In recent years a number of authors have flatly denied these allegations. David F. Musto, a psychiatrist and historian, has argued that "These fantasies characterized white fear, not the reality of cocaine's effects . ..." "41 Richard Ashley has also dismissed them as "fear-mongering fantasies," while Joël L. Phillips and Ronald D. Wynne conclude that "No reputable researchers have uncovered any statistical or other type of evidence to indicate that the use of cocaine resulted in a massive (black) crime wave." 42

Why, then, did so many contemporaries make the link between blacks, cocaine, and crime? One possible explanation is that they had ulterior political motives. Hamilton Wright, for example, may have used the cocaine stories in an effort to secure the support of Negrophobic southern congressmen for pending antinarcotic legislation. Similarly, Edward Williams was an antiprohibitionist who, by suggesting that when blacks were denied liquor they switched to cocaine, may have been attempting to persuade the public that alcohol was the lesser of two evils. Beyond discrediting the testimony of Drs. Williams and Wright, Musto has also suggested that, in general, the cocaine stories served as a further excuse to repress and disfranchise blacks and as a convenient explanation for crime waves. ${ }^{43}$

While there is much validity in these arguments, and while it is virtually certain that there was no massive wave of cocaine-related crime, there may be additional reasons why so many authorities made this association. One possibility is that they were simply repeating a legend, a legend based upon a few scattered incidents. It is not impossible to imagine that a "hitherto inoffensive, lawabiding negro," as Dr. Williams described him, chafing under accumulated slurs and outrages, might, under the influence of cocaine, vent his rage on a white person, especially a white policeman. Such an attack might represent genuine cocaine psychosis or simply relaxed inhibitions combined with long-standing grievances. ${ }^{44}$

${ }^{42}$ Musto, American Disease, 7.

42 Richard Ashley, Cocaine: Its History, Uses and Effects (New York, 1975), 67-72 (quotation on p. 68); Phillips and Wynne, Cocaine: The Mystique and the Reality (New York, 1980), 64-71 (quotation on p. 68).

${ }^{13}$ Musto, American Disease, 7, 43-44, 254-55 n. 15, 256 n. 20; Joseph L. Zentner, "Cocaine and the Criminal Sanction," Journal of Drug Issues, VII (Spring 1977), 97-98, follows Musto's argument closely.

"The quotation by Dr. Williams is from his "Drug-Habit Menace in the South," 247. For specific incidents of violent crimes committed by blacks allegedly under the influence of cocaine see Werner, "Illegal Sale," 84-85; and "10 Killed, 35 Hurt in Race Riot Born of Cocaine 'Jag'," New York Herald, September 29, 1913, p. 1. Significantly, whites were also sometimes observed to engage in violent or vengeful behavior under the influence of cocaine. For example, T. D. Crothers, “Cocainism," Journal of Inebriety, XXXII (Summer 1910), 80; "Aaron Martin Sold 470 Ounces of Cocaine"; and Henry O. Whiteside, "The Drug 
Given the supercharged racial atmosphere of the South, it would take only a few such episodes to fashion a full-fledged cocaine "menace." The fear of cocaine-sniffing blacks was thus not unlike the fear of slave rebellion which swept the South after Nat Turner's short-lived foray; both were exaggerated reactions to isolated but potently symbolic deeds. A second likely explanation involves the background of black cocaine users, especially those who lived in cities. As New Orleans police inspector William J. O'Connor put it, they often belonged to the "immoral and lower" elements of the black community. ${ }^{45}$ Some of them were, in other words, already involved in a range of criminal activities, and a white authority, aware that they also sniffed cocaine, could easily have inferred that cocaine caused the crimes: post hoc, ergo propter hoc.

Finally, there is a sense in which cocaine indirectly contributed to crimes against property. Regular cocaine use could be expensive, especially after restrictive state legislation increased its price; therefore many impoverished black users would have had to resort to petty crime in order to obtain the drug. Once again an observerparticularly one who had heard other cocaine-crime stories-could well have drawn the inference that the action of the drug itself, rather than the lack of money to purchase it, had inspired the deed. A similar mistake was made during the early 1920 s, when it was commonly believed that heroin, rather than the addicts' compulsion to obtain it, was a direct incentive to crime. ${ }^{46}$ Thus, the widespread belief that cocaine caused blacks to commit crimes, which perhaps originated in one or two bona fide episodes, was sustained and expanded by a false sense of causation. The legend grew when Wright and Williams, both physicians with apparently impeccable credentials, used it to suit their own political ends.

Exaggerated fears of black cocaine rampages may also have had the effect of drawing attention from the real southern drug problem-opiates-and obscuring the majority of the real victimswhite medical addicts. Opiate addicts were, in any event, ailing, secretive, and heavily tranquilized individuals, reluctant to come into the public eye. Their reluctance was due, in large measure, to unfavorable attitudes toward addicts. Prior to 1870 most Americans-including physicians-regarded opiate addiction as a vice, a

Habit in Nineteenth-Century Colorado," Colorado Magazine, LV (Winter 1978), 64. See also Phillips and Wynne, Cocaine, 162-63.

"O'Connor to Wright, June 22, 1909, USIOC Records. "As a rule," noted Acting Chief W. P. Ford of Norfolk, Va., "the lowest class of white's [sic] and negroes . . . [use it]; 'Sniffing' is (or was) mostly indulged by white and negro prostitutes, the latter being given to the practice, to a considerably greater extent than the former." Ford to Wright, June 18, 1909, ibid. See also Werner, "Illegal Sale," 84.

"See, for example, The Case Against Heroin . . . (Foreign Policy Association Pamphlet No. 24, New York, 1924), 4. 
bad habit indulged in by the weak-willed and the sinful. Even though they may have originally received the drug from a doctor, the addicts continued taking it, according to one Methodist minister, because "They learn to love the excitement which it produces .... ",47

After 1870, however, a small but growing number of physicians, most of whom specialized in treating addicted and alcoholic patients, challenged this prevailing view. They argued that opiate addiction was a variety of a more general condition called inebriety and that inebriety was a functional disease triggered by an underlying mental disturbance. An individual who had, for example, either inherited or acquired a weakened, nervous constitution was thought to be more susceptible than a neurologically normal person. It followed that opiate addiction was not necessarily a vice but was more often a manifestation of a genuine disease. Advocates of this position, who established the American Association for the Cure of Inebriates in 1870 and began publishing a house organ called the Quarterly Journal of Inebriety in 1876, had considerable influence in both northern and southern medical circles. ${ }^{48}$ It is doubtful, however, that they drastically changed the attitudes of most ordinary men and women, whose understanding of such matters was shaped less by specialized journals than by gossip, stereotypes, and the strictures of evangelical Protestantism. So, as a practical matter, most addicts continued to conceal their condition from relatives and neighbors, even as medical interpretations of their plight were beginning to change during the closing decades of the nineteenth century.

Thus, the spread of opiate addiction through the South after 1860 was, in many respects, a hidden epidemic. The roots of this epidemic were the presence of endemic infectious and parasitic diseases and the lingering trauma, physical and psychological, of the Civil War. The principal reason for the unbalanced racial distribution of opiate addiction was that blacks generally lacked access to professional medical care. The age distribution of blacks and their partial immunity to malarial diseases may also have played a role. The epilogue of this story is that blacks were not significantly afflicted by opiate addiction until they left the South and began settling in large numbers in the drug-ridden tenderloins and ghettos of northern cities.

4' J. Townley Crane, "Drugs as an Indulgence," Methodist Quarterly Review, XL (October 1858$), 562$.

"A A[rnold] Jaffe, "Reform in American Medical Science: The Inebriety Movement and the Origins of the Psychological Disease Theory of Addiction, 1870-1920," British Journal of Addiction to Alcohol and Other Drugs, LXXIII (June 1978), 139-47. For further details, see Chapter 5 of David T. Courtwright, Dark Paradise: Opiate Addiction in America Before 1940 (Cambridge, Mass., and London, 1982). 